\title{
Assessing the Linkages between Tree Species Composition and Stream Water Nitrate in a Reference Watershed in Central Appalachia
}

\author{
Mark B. Burnham ${ }^{1, *(D)}$, Martin J. Christ ${ }^{2}$, Mary Beth Adams ${ }^{3}$ and William T. Peterjohn ${ }^{4}$ \\ 1 Center for Advanced Bioenergy and Bioproducts Innovation, University of Illinois at Urbana-Champaign, \\ Urbana, IL 61801, USA \\ 2 West Virginia Department of Environmental Protection, Fairmont, WV 26554, USA; Martin.J.Christ@wv.gov \\ 3 USDA Forest Service Northern Research Station, Morgantown, WV 26505, USA; mbadams@fs.fed.us \\ 4 Department of Biology, West Virginia University, Morgantown, WV 26505, USA; \\ William.Peterjohn@mail.wvu.edu \\ * Correspondence: mburnham@illinois.edu
}

check for updates

Citation: Burnham, M.B.; Christ, M.J.; Adams, M.B.; Peterjohn, W.T. Assessing the Linkages between Tree Species Composition and Stream Water Nitrate in a Reference Watershed in Central Appalachia. Forests 2021, 12, 1116. https://doi.org/10.3390/ f12081116

Academic Editor: Thomas H. DeLuca

Received: 3 June 2021

Accepted: 17 August 2021

Published: 20 August 2021

Publisher's Note: MDPI stays neutral with regard to jurisdictional claims in published maps and institutional affiliations.

Copyright: (c) 2021 by the authors. Licensee MDPI, Basel, Switzerland. This article is an open access article distributed under the terms and conditions of the Creative Commons Attribution (CC BY) license (https:/ / creativecommons.org/licenses/by/ $4.0 /)$.

\begin{abstract}
Many factors govern the flow of deposited nitrogen $(\mathrm{N})$ through forest ecosystems and into stream water. At the Fernow Experimental Forest in $\mathrm{WV}$, stream water nitrate $\left(\mathrm{NO}_{3}{ }^{-}\right)$export from a long-term reference watershed (WS 4) increased in approximately 1980 and has remained elevated despite more recent reductions in chronic $\mathrm{N}$ deposition. Long-term changes in species composition may have altered forest $\mathrm{N}$ demand and the retention of deposited $\mathrm{N}$. In particular, the abundance and importance value of Acer saccharum have increased since the 1950s, and this species is thought to have a low affinity for $\mathrm{NO}_{3}{ }^{-}$. We measured the relative uptake of $\mathrm{NO}_{3}{ }^{-}$and ammonium $\left(\mathrm{NH}_{4}{ }^{+}\right)$ by six important temperate broadleaf tree species and estimated stand uptake of total $\mathrm{N}, \mathrm{NO}_{3}{ }^{-}$, and $\mathrm{NH}_{4}{ }^{+}$. We then used records of stream water $\mathrm{NO}_{3}{ }^{-}$and stand composition to evaluate the potential impact of changes in species composition on $\mathrm{NO}_{3}{ }^{-}$export. Surprisingly, the tree species we examined all used both mineral $\mathrm{N}$ forms approximately equally. Overall, the total $\mathrm{N}$ taken up by the stand into aboveground tissues increased from 1959 through 2001 (30.9 to $35.2 \mathrm{~kg} \mathrm{~N} \mathrm{ha}^{-1} \mathrm{yr}^{-1}$ ). However, changes in species composition may have altered the net supply of $\mathrm{NO}_{3}{ }^{-}$in the soil since A. saccharum is associated with high nitrification rates. Increases in A. saccharum importance value could result in an increase of $3.9 \mathrm{~kg} \mathrm{NO}_{3}{ }^{-}-\mathrm{N} \mathrm{ha}^{-1} \mathrm{yr}^{-1}$ produced via nitrification. Thus, shifting forest species composition resulted in partially offsetting changes in $\mathrm{NO}_{3}{ }^{-}$supply and demand, with a small net increase of $1.2 \mathrm{~kg} \mathrm{~N}^{-1} \mathrm{yr}^{-1}$ in $\mathrm{NO}_{3}{ }^{-}$available for leaching. Given the persistence of high stream water $\mathrm{NO}_{3}{ }^{-}$export and relatively abrupt ( 9 year) change in stream water $\mathrm{NO}_{3}{ }^{-}$ concentration circa 1980, patterns of $\mathrm{NO}_{3}{ }^{-}$export appear to be driven by long-term deposition with a lag in the recovery of stream water $\mathrm{NO}_{3}{ }^{-}$after more recent declines in atmospheric $\mathrm{N}$ input.
\end{abstract}

Keywords: watershed biogeochemistry; nitrogen cycle; nitrification; nitrogen uptake; nitrate export; Acer saccharum

\section{Introduction}

The northeastern United States experienced relatively high atmospheric $\mathrm{N}$ deposition during the latter half of the 20th century [1,2], increasing $\mathrm{N}$ supply into some forested ecosystems enough that the availability of $\mathrm{N}$ exceeded stand $\mathrm{N}$ demand-a situation that can cause significant nitrate $\left(\mathrm{NO}_{3}{ }^{-}\right)$leaching [3]. Substantial loss of $\mathrm{NO}_{3}{ }^{-}$contributes to an associated leaching of base cations, such as calcium and magnesium, which are important to plant growth [4-6], and may also have negative effects downstream [1]. Since the passage and subsequent amendment of the Clean Air Act, national emissions of $\mathrm{NO}_{x}$ and atmospheric $\mathrm{N}$ deposition have steadily declined; however, the response of forested catchments is variable. Some have lower $\mathrm{N}$ export following national emission 
and deposition trends, while the levels of $\mathrm{N}$ export in others remain high and result in declining inorganic N retention [7-9]. Given the ecological implications of N export into stream water, it is important to understand what controls watershed responses to changes in $\mathrm{N}$ deposition through time.

Many factors (both belowground and aboveground) can affect the retention and export of $\mathrm{N}$ deposited into forests [10]. Below ground, soil organic matter is the largest pool of $\mathrm{N}$ in temperate forests and is a major sink for added $\mathrm{N}$ [11]. Microbial immobilization, plant uptake, mineralization, and nitrification control mineral $\mathrm{N}$ availability in the soil [12], and net nitrification has a large impact on $\mathrm{N}$ export due to the mobility of $\mathrm{NO}_{3}{ }^{-}$in soils. Above ground, stand age has a large impact on $\mathrm{N}$ retention, as young, aggrading stands usually retain more $\mathrm{N}$ due to greater $\mathrm{N}$ demand [10]. Even between stands of similar age, differences in species composition can lead to differences in $\mathrm{N}$ retention and loss [3,13-16]. As a result, gradual changes in species composition through time could also impact watershed $\mathrm{N}$ retention but are more challenging to study due to the need for long-term records.

Fortunately, there are long-term records of changes in both stream-water $\mathrm{NO}_{3}{ }^{-}$(since 1970) and the composition of tree species (since 1959) in a reference watershed (WS 4) at the Fernow Experimental Forest (FEF) in the central Appalachian Mountains of West Virginia. From 1975 to 1984 , there was a $435 \%$ increase (1.3 to $6.9 \mathrm{~kg} \mathrm{~N} \mathrm{ha}^{-1} \mathrm{yr}^{-1}$ ) in stream water $\mathrm{NO}_{3}{ }^{-}$export, and one assessment of 24 watersheds in the eastern United States found that WS 4 at the FEF had the lowest retention of inorganic $\mathrm{N}$ among those examined [17]. This relatively abrupt increase in stream water $\mathrm{NO}_{3}{ }^{-}$export along with other changes in stream water chemistry were likely symptoms of nitrogen saturation caused by long-term $\mathrm{N}$ deposition [18]. In addition, nearby measurements show a significant increase in the importance of $A$. saccharum through time [19], which is a species associated with high rates of $\mathrm{NO}_{3}{ }^{-}$production. The maintenance of high $\mathrm{NO}_{3}{ }^{-}$export from WS 4 despite a reduction in $\mathrm{N}$ deposition suggests that long-term changes within the watershed may be responsible, and that these changes may not be quickly reversed. Thus, long-term data sets for WS 4 afford the unique opportunity to assess the potential impact of changes in stand species composition on stream water $\mathrm{NO}_{3}{ }^{-}$loss and its potentially long-lasting effect on inorganic $\mathrm{N}$ retention.

Tree species composition could impact $\mathrm{N}$ retention due to interspecific differences in rate of total $\mathrm{N}$ uptake, and interspecific differences in their reliance on different forms of mineral N. Relatively slow-growing Fagus species, as well as coniferous species, tend to have lower rates of total $\mathrm{N}$ uptake, while other species, including $A$. saccharum and European Fraxinus and Tilia species, have higher rates of $\mathrm{N}$ uptake [20-23]. Therefore, should species with different $\mathrm{N}$ uptake requirements change in relative abundance, the overall stand demand for $\mathrm{N}$ could shift and alter watershed $\mathrm{N}$ retention.

Similarly, differences among species with respect to the mineral forms of $\mathrm{N}$ they prefer could also affect watershed $\mathrm{N}$ retention if the composition of tree species is altered. The relative uptake of different forms of $\mathrm{N}$ varies from species that rely mostly on $\mathrm{NO}_{3}{ }^{-}[24]$, to species that prefer $\mathrm{NH}_{4}{ }^{+}$[25-28], to species that change their preference to match the form that is most available [29,30]. More specifically, A. saccharum trees, which are often abundant in northeastern and Appalachian deciduous forests, may have a strong preference for $\mathrm{NH}_{4}{ }^{+}$[21,31-34]. While many other trees also preferentially take up $\mathrm{NH}_{4}{ }^{+}$, some acquire most of their $\mathrm{N}_{\text {as }} \mathrm{NO}_{3}{ }^{-}$[22]. Indeed, seedlings of several species found in central Appalachian forests (Fagus grandifolia, Tsuga canadensis, Quercus rubra, and Betula lenta) either take up more $\mathrm{NO}_{3}{ }^{-}$than $\mathrm{NH}_{4}{ }^{+}$[21], or grow better under $\mathrm{NO}_{3}{ }^{-}$additions [35]. Thus, both the total uptake of $\mathrm{N}$ and the variability in relative uptake of different mineral $\mathrm{N}$ forms by overstory trees could impact $\mathrm{NO}_{3}{ }^{-}$losses following shifts in stand species composition.

Given the variation between species in both total $\mathrm{N}$ uptake and relative utilization of different mineral forms, it is interesting that the importance of A. saccharum in the FEF has increased substantially over the past century [19]. Since this species appears to strongly prefer $\mathrm{NH}_{4}{ }^{+}$, a shift towards a greater influence of A. saccharum on the overall 
community could partially explain the maintenance of stream water $\mathrm{NO}_{3}{ }^{-}$exhibited in FEF WS 4 despite recent reductions in $\mathrm{N}$ deposition, particularly if the species it replaces preferentially utilizes $\mathrm{NO}_{3}{ }^{-}$. In addition, A. saccharum in the FEF is associated with soils having higher $\mathrm{NO}_{3}{ }^{-}$production rates and higher soil water $\mathrm{NO}_{3}{ }^{-}$concentrations at the scale of individual trees, plots, and entire watersheds [15]. Thus, an increase in the relative importance of this species may not only diminish the demand for $\mathrm{NO}_{3}{ }^{-}$but also increase its supply. These combined effects indicate that shifts in species composition and stand $\mathrm{NO}_{3}{ }^{-}$utilization may contribute to the temporal trends observed in stream $\mathrm{NO}_{3}{ }^{-}$export from WS 4.

To assess whether changing tree species composition in WS 4 could reduce long-term watershed $\mathrm{N}$ retention, we took advantage of the relatively unique stand inventory and stream water chemistry data at the FEF by coupling these data with in situ measurements of $\mathrm{NO}_{3}{ }^{-}$versus $\mathrm{NH}_{4}{ }^{+}$preference for the dominant, overstory tree species found at this location. This combination of data was then used to estimate total $\mathrm{N}$ uptake and temporal changes in stand composition in order to evaluate the hypothesis that changes in species composition at this site have contributed to elevated $\mathrm{NO}_{3}{ }^{-}$export in stream water.

\section{Materials and Methods}

\subsection{Study Site}

The focus of this study was a long-term reference watershed and a nearby untreated stand at the FEF. The reference watershed (WS 4) is 39 ha at an average elevation of $792 \mathrm{~m}$ and has a southeastern aspect. The predominant soil type is a Calvin channery silt loam (loamy-skeletal, mixed, mesic Typic Dystrochrept), and the average annual precipitation is $\sim 145 \mathrm{~cm}$ [36]. The forest in WS 4-and the entire FEF-was heavily cut in approximately 1905-1910, and since that time the forest in WS 4 has been left uncut and untreated. WS 4 is dominated by temperate broadleaf trees, with Quercus spp., Acer spp., Liriodendron tulipifera, and Prunus serotina making up $>75 \%$ of the tree stems. In this watershed, the forest canopy is closed along the drainage and there is no clear delineation separating the riparian zone from surrounding areas and no discernable difference in riparian vegetation compared to that of the surrounding slopes.

Continuous stream flow measurements for WS 4 began in 1951 [37], and weekly or bi-weekly stream water samples have been analyzed for their $\mathrm{NO}_{3}{ }^{-}$concentration since 1970 [36]. All precipitation and stream water chemistry variables were measured using EPA-approved protocols by the USDA Forest Service's Timber and Watershed Laboratory in Parsons, WV. The analyses and quality control measures are detailed by Edwards and Wood, 1993 [38]. From 1975 through 1984, $\mathrm{NO}_{3}{ }^{-}$export in stream water increased by $5.6 \mathrm{~kg} \mathrm{~N} \mathrm{ha}^{-1} \mathrm{yr}^{-1}(\sim 435 \%)$; since that time, $\mathrm{NO}_{3}{ }^{-}$levels have remained elevated, with fairly regular $\sim 5-10$ year oscillations (Figure 1). Stream water $\mathrm{NH}_{4}{ }^{+}$concentrations average $\sim 0.05 \%$ of $\mathrm{NO}_{3}{ }^{-}$concentrations, and although dissolved organic $\mathrm{N}$ is not regularly measured in stream water at this site, one year of measurements in the 1995 show that $\sim 87 \%$ of $\mathrm{N}$ export is as $\mathrm{NO}_{3}{ }^{-}$; thus, we focused on stream water $\mathrm{NO}_{3}{ }^{-}$export. Historically, the area has received high rates of $\mathrm{N}$ deposition (Figure 1), with total (wet + dry) deposition estimated to be $\sim 10 \mathrm{~kg} \mathrm{~N} \mathrm{ha}^{-1}$ year $^{-1}$ from 1986 to 2002 [15].

\subsection{Species Composition and Stand N Uptake}

Complete inventories of all trees in WS 4, including the total number of live trees of all species in 2 inch diameter at breast height (DBH) categories, were completed by the US Forest Service in 1959, 1964, 1972, 1984, and 2001 [39]. To investigate changes in species composition, we calculated relative importance value (RIV) for each species in each inventory year as the average of its relative abundance (RA, the number of stems of that species divided by the total number of tree stems) and its relative basal area (RBA, the basal area of that species divided by the total tree basal area). 


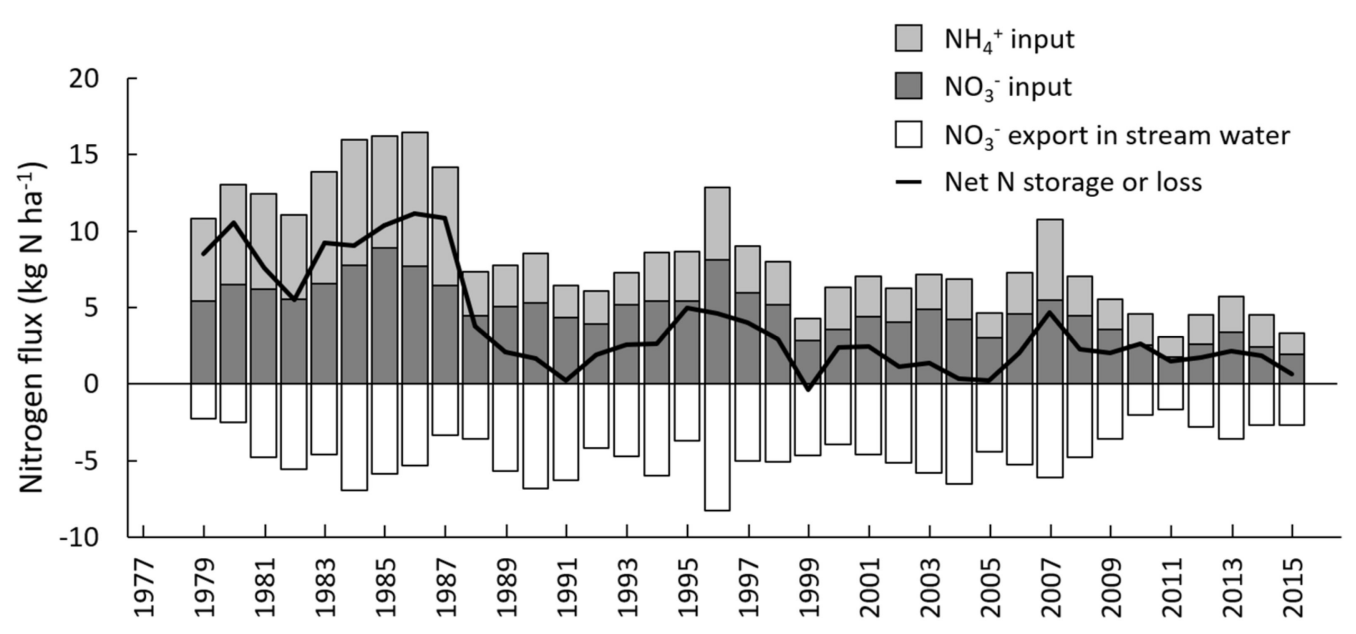

Figure 1. Annual $\mathrm{NH}_{4}{ }^{+}$and $\mathrm{NO}_{3}{ }^{-}$inputs into and stream $\mathrm{NO}_{3}{ }^{-}$export from FEF WS 4 , and the net $\mathrm{N}$ storage or loss from the catchment. Export of $\mathrm{NH}_{4}{ }^{+}$in stream water is negligible $\left(\sim 0.05 \%\right.$ of $\mathrm{NO}_{3}{ }^{-}$export).

We estimated the total $\mathrm{N}$ uptake by the trees in WS 4 as the sum of annual $\mathrm{N}$ storage in aboveground woody biomass and annual $\mathrm{N}$ return to the soil via litterfall. Complete forest inventory data (1959-2001) were used to estimate annual woody N storage, and since these were $100 \%$ live-tree inventories, tree death is accounted for in these measurements, and in our estimates. To determine the $\mathrm{N}$ concentration in aboveground woody tissue, trees greater than $8 \mathrm{~cm}$ in DBH were cored in 16 plots (10 m radius) spread evenly throughout WS 4 in the summer of 1998 (Christ and others 2002). Using these cores, the width of the last 5 growth rings was measured, and the wood within $1 \mathrm{~cm}$ of the bark was ground and analyzed for N concentration by Dumas combustion [40] using a Carlo Erba 1500 CNS elemental analyzer. The total aboveground woody biomass of each tree was estimated with FEF-specific allometric equations [41], and annual $\mathrm{N}$ storage was then calculated as the product of annual biomass increment and woody tissue $\mathrm{N}$ concentration. Using the $\mathrm{DBH}$ and annual $\mathrm{N}$ storage, a regression equation was built to estimate the annual woody $\mathrm{N}$ storage based on the DBH of any tree in the watershed $\left(R^{2}=0.790\right)$ :

$$
\log (\text { annual woody } N \text { storage })=-2.256+2.182 \log (\mathrm{DBH})+a
$$

where $a$ is a species-specific constant (Table A1) based on the average residual for each species (Christ and Peterjohn, unpublished data).

Total autumnal litter fall mass ( $\sim$ September through December) was collected annually beginning in 1988 by the US Forest Service using 25 litter traps throughout the watershed ( $0.7679 \mathrm{~m}^{2}$ wooden frames with bottoms of $\sim 0.625 \times 0.625 \mathrm{~cm}$-opening metal mesh). A relationship between autumnal litter fall and total stand basal area was created using the total basal area measured at 13 long-term growth plots in WS 4, and the total litter fall measured in 1989, 1994, 1999, and $2009\left(R^{2}=0.887\right)$. Using this relationship, we estimated total litter fall for the years of stand inventories prior to the start of the collection of litterfall data $(1959,1964,1972$, and 1984). We then estimated each species' litter $\mathrm{N}$ returns for all inventory years using the relationships between a tree species' RBA and the species-specific litterfall $\mathrm{N}$ contents at 16 plots in 1998 [13].

\section{3. ${ }^{15} \mathrm{~N}$ Labeling}

To avoid affecting the $\delta^{15} \mathrm{~N}$ of materials in the long-term reference watershed, we used a "test area" located in a nearby untreated area of the FEF $(<1 \mathrm{~km}$ from WS 4$)$ to measure the relative uptake of $\mathrm{NO}_{3}{ }^{-}$versus $\mathrm{NH}_{4}{ }^{+}$. This area has a similar elevation, slope, and tree composition to WS 4, and an east-northeasterly aspect. Unlike WS 4, small (0.2-ha) plots in this portion of the FEF were harvested to selected basal areas in the 1980s. However, 
for this study we selected trees within an area showing no signs of harvest, and the trees selected were of similar size to those in WS 4 .

At our "test area" in early July 2014, we conducted a ${ }^{15} \mathrm{~N}$-labeling experiment similar to one by performed by McKane et al. [42] to determine the relative uptake of $\mathrm{NH}_{4}{ }^{+} \mathrm{vs}$. $\mathrm{NO}_{3}{ }^{-}$for 6 major tree species at the FEF: A. rubrum, A. saccharum, B. lenta, L. tulipifera, Q. rubra, and P. serotina. We used the holes in pieces of commercial peg board $\left(625 \mathrm{~cm}^{2} \mathrm{each}\right.$, with 10 rows $\times 10$ columns of holes spaced $2.54 \mathrm{~cm}$ apart) to evenly space injections of $3.5 \mathrm{mM}^{15} \mathrm{~N}$ as $\mathrm{K}^{15} \mathrm{NO}_{3}$ in one area (1 mL per hole), and $3.5 \mathrm{mM}{ }^{15} \mathrm{~N}$ as ${ }^{15} \mathrm{NH}_{4} \mathrm{Cl}$ in another area under the canopy (within $\sim 3 \mathrm{~m}$ of the trunk) of five mature trees of each species. The solutions were injected midday at approximately the boundary between organic and mineral soil horizons - a depth of $\sim 3 \mathrm{~cm}$ - using a syringe needle with four side ports. Based on the soil $\mathrm{NH}_{4}{ }^{+}$and $\mathrm{NO}_{3}{ }^{-}$concentrations, we estimate that this injection increased background $\mathrm{N}$ concentrations by $10 \%$ and $5 \%$, respectively. After three hours, we harvested fine roots ( $<2 \mathrm{~mm}$ diameter) from a depth of $\sim 3 \mathrm{~cm}$ at each injection site, and roots from one unlabeled area under each tree to measure the natural ${ }^{15} \mathrm{~N}$ abundance of root tissue. The sampled roots were traced as far as possible towards the target canopy tree, and we compared the morphology of the collected roots to the fine roots of nearby seedlings of the same species. All species had distinct root characteristics except the two Acer species. Thus, we selected $A$. saccharum and $A$. rubrum trees that had no nearby Acer spp. within $\sim 15 \mathrm{~m}$.

All harvested roots were placed on ice and transported to the lab, where they were soaked in $1 \mathrm{M} \mathrm{CaSO}_{4}$ for 1 min to remove unassimilated $\mathrm{N}$ from the Donnan free space [43]. They were then dried at $65^{\circ} \mathrm{C}$ for $48 \mathrm{~h}$ and ground to a fine powder in a dental amalgamator (Henry Schein, Inc., Melville, NY, USA). Approximately $5 \mathrm{mg}$ of each sample was wrapped in tin capsules and analyzed for $\delta^{15} \mathrm{~N}$ via isotope ratio gas chromatography-mass spectrometry at the Central Appalachian Stable Isotope Facility that is part of the University of Maryland Center for Environmental Science Appalachian Laboratory (Frostburg, MD, USA).

We calculated root uptake of ${ }^{15} \mathrm{~N}$ from the labeled $\mathrm{N}$ pool as described in Burnham and others [44]. We first converted $\delta^{15} \mathrm{~N}$ values to the fraction of the heavy isotope in the sample $(F)$ using the ${ }^{15} \mathrm{~N} /{ }^{14} \mathrm{~N}$ ratio in each sample $\left(R_{\text {sample }}\right)$ [45]:

$$
\begin{gathered}
R_{\text {sample }}=\left(\left(\frac{\delta^{15} N}{1000}\right) * R_{\text {std }}\right)+R_{\text {std }} \\
F=\frac{R_{\text {sample }}}{1+R_{\text {sample }}}
\end{gathered}
$$

where $R_{\text {std }}={ }^{15} \mathrm{~N} /{ }^{14} \mathrm{~N}$ ratio in atmospheric $\mathrm{N}_{2}(0.0036764)$. Using the root tissue $N$ content and $F$, we calculated the $\mu \mathrm{mol}{ }^{15} \mathrm{~N} \mathrm{~g}^{-1}$ root, and then estimated the rate of ${ }^{15} \mathrm{~N}$ uptake from the ${ }^{15} \mathrm{~N}$-labeled pools by dividing the ${ }^{15} \mathrm{~N}$ excess $\left({ }^{15} \mathrm{~N}\right.$ content of labeled-unlabeled roots from the same tree) by the exposure time $(3 \mathrm{~h})$. Finally, we calculated total uptake of ${ }^{15} \mathrm{~N}$ label $\left({ }^{15} \mathrm{NH}_{4}{ }^{+}+{ }^{15} \mathrm{NO}_{3}{ }^{-}\right)$and the percent that was taken up as $\mathrm{NH}_{4}{ }^{+}$and $\mathrm{NO}_{3}{ }^{-}$.

\subsection{Data Analysis}

Our overall ${ }^{15} \mathrm{~N}$ label study design included six species, and five trees per species, with a measurement of $\mathrm{NO}_{3}{ }^{-}$vs. $\mathrm{NH}_{4}{ }^{+}$uptake associated with each tree. We used a nested ANOVA with Tukey's HSD post hoc test $(\alpha=0.05)$ to determine if the percent of total $\mathrm{N}$ taken up as $\mathrm{NO}_{3}{ }^{-}$varied by species. The model included the effect of tree nested within species. We then performed one-tailed $t$-tests to determine if the contribution of $\mathrm{NO}_{3}{ }^{-}$ to total uptake of $\mathrm{N}$ from the labeled pool was greater than $50 \%$, which would indicate a significant preference of $\mathrm{NO}_{3}{ }^{-}$over $\mathrm{NH}_{4}{ }^{+}$.

We used the error terms in our plot-level RBA vs. leaf litter $\mathrm{N}$ return and BA vs. woody $\mathrm{N}$ storage models to run a Monte Carlo simulation to estimate the uncertainty in our total stand $\mathrm{N}$ uptake calculations. For this simulation, we assumed errors were normally distributed and randomly sampled 100 times from the error distribution, and we 
report uncertainty estimates in woody $\mathrm{N}$ storage, litter $\mathrm{N}$ return, and total $\mathrm{N}$ uptake are reported as $95 \%$ confidence intervals.

\section{Results}

From 1959 to 2001, total stand density in WS 4 decreased $18 \%$ (from 372 to 305 trees ha ${ }^{-1}$ ) and total stand basal area increased $45 \%$ (from 24.3 to $35.2 \mathrm{~m}^{2} \mathrm{ha}^{-1}$ ). In 2001, eight species accounted for $\sim 85 \%$ of the stand composition ( $84.6 \%$ of stems and $85.8 \%$ of basal area): Quercus rubra, Q. prinus, Acer saccharum, A. rubrum, Liridendron tulipifera, Prunus serotina, Betula lenta, and Fagus grandifolia. Over the study period, five of these species increased in RIV, and three decreased (Figure 2). The RIVs of $A$. saccharum and A. rubrum increased 5.8 and $8.5 \%$, respectively, the most of any species. While the RIV of $A$. saccharum increased, its relative basal area decreased slightly $(1.4 \%)$ and the number of stems increased substantially (from $8.9 \%$ to $21.9 \%$ ) throughout the period examined. The RIV of $Q$. rubra increased to a more modest degree $(2.9 \%)$, with its relative basal area increasing from $22.6 \%$ to $32.3 \%$ and its relative abundance decreasing from $20.4 \%$ to $16.7 \%$ throughout the study period. The RIV of $Q$. prinus, B. lenta, and F. grandifolia all declined through the study period (Figure 2). The RIV of $Q$. prinus fell from $6.8 \%$ to $5.6 \%$, and the RIV of $B$. lenta fell from $6.9 \%$ to $3.8 \%$. While there was only a slight decline in the RIV of F. grandifolia, from $4.1 \%$ to $3.7 \%$, its relative basal area fell from $5.4 \%$ of the stand to $3.4 \%$, but its relative abundance increased from $2.8 \%$ to $4.0 \%$.

Aboveground woody $\mathrm{N}$ storage increased from $6.4(6.1-6.795 \% \mathrm{CI})$ to 9.8 (9.2-10.4) $\mathrm{kg} \mathrm{N} \mathrm{ha}^{-1} \mathrm{yr}^{-1}(+53.5 \%)$ and litter $\mathrm{N}$ return increased from 24.5 (19.3-29.7) to $25.4(21.8-29.0) \mathrm{kg} \mathrm{N}^{-1} \mathrm{yr}^{-1}(+3.5 \%)$ over this period. In total, stand $\mathrm{N}$ uptake increased from $30.9(25.7-36.1) \mathrm{kg} \mathrm{N} \mathrm{ha}^{-1} \mathrm{yr}^{-1}$ in 1959 to $35.2(31.7-38.7) \mathrm{kg} \mathrm{N} \mathrm{ha}^{-1} \mathrm{yr}^{-1}$ in $2001(+13.8 \%)$. The percent of mineral $\mathrm{N}$ uptake as $\mathrm{NO}_{3}{ }^{-}$ranged from $52.7 \%$ (L. tulipifera) to $75.3 \%$ (A. rubrum) but was not significantly different between species (Table 1 ). When these rates of $\mathrm{NO}_{3}{ }^{-}$vs. $\mathrm{NH}_{4}{ }^{+}$uptake were applied to the estimates of total $\mathrm{N}$ uptake within the watershed, $\mathrm{NO}_{3}{ }^{-}$uptake increased from 18.7 to $21.4 \mathrm{~kg} \mathrm{~N} \mathrm{ha}^{-1} \mathrm{yr}^{-1}(14.5 \%)$, and $\mathrm{NH}_{4}{ }^{+}$uptake increased from 12.2 to $13.8 \mathrm{~kg} \mathrm{~N} \mathrm{ha}^{-1} \mathrm{yr}^{-1}$ (12.8\%) from 1959 to 2001. The percent of total stand uptake of $\mathrm{N}$ taken up as $\mathrm{NO}_{3}{ }^{-}$thus increased only $0.4 \%$.

Table 1. The percent of total uptake of mineral $\mathrm{N}$ as $\mathrm{NO}_{3}{ }^{-}$for six major overstory trees at the FEF, measured in situ using ${ }^{15} \mathrm{~N}$-labeled $\mathrm{NO}_{3}{ }^{-}$and $\mathrm{NH}_{4}{ }^{+}$.

\begin{tabular}{cc}
\hline Species & Percent of $\mathbf{N}$ Uptake as $\left.\mathbf{N O}_{\mathbf{3}} \mathbf{~} \mathbf{(} \pm \mathbf{S E}\right)^{\text {A. rubrum }}$ \\
A. saccharum & $75.3( \pm 12.5)$ \\
B. lenta & $53.6( \pm 16.0)$ \\
L. tulipifera & $54.7( \pm 11.5)$ \\
P. serotina & $52.7( \pm 13.0)$ \\
Q. rubra & $61.6( \pm 11.3)$ \\
\hline
\end{tabular}

Prior studies, using other methods and some using more sampling dates, found much lower rates of $\mathrm{N}$ uptake as $\mathrm{NO}_{3}{ }^{-}$by $A$. saccharum (average of $15.8 \%$, vs. $53.6 \%$ in this study) (Table 2). Given the range of values reported for the affinity of $A$. saccharum for $\mathrm{NO}_{3}{ }^{-}$, we assessed the potential impact that changes in this particular species might have on stand uptake of $\mathrm{NO}_{3}{ }^{-}$by considering two scenarios. First, we used the average relative contribution of $\mathrm{NO}_{3}{ }^{-}$to tree uptake of $\mathrm{N}(15.8 \%)$ reported in previous studies. Second, we used the average of all available estimates of $\mathrm{NO}_{3}{ }^{-}$uptake by A. saccharum, which raised the average to $23.4 \%$. In both scenarios, to estimate stand uptake of $\mathrm{NO}_{3}{ }^{-}$we used the average of our measured values of $\mathrm{NO}_{3}{ }^{-}$uptake for all unmeasured species. For the first scenario, when values from previous studies were applied to the estimates of total $\mathrm{N}$ uptake within WS 4 at the $\mathrm{FEF}, \mathrm{NO}_{3}{ }^{-}$uptake increased from 17.5 to $20.3 \mathrm{~kg} \mathrm{~N} \mathrm{ha}^{-1} \mathrm{yr}^{-1}$ (2.8\%) and $\mathrm{NH}_{4}{ }^{+}$uptake increased from 13.4 to $14.9 \mathrm{~kg} \mathrm{~N} \mathrm{ha}^{-1} \mathrm{yr}^{-1}$ (1.5\%) from 1959 to 2001. Under this scenario, the percent of total stand uptake of $\mathrm{N}^{-} \mathrm{NO}_{3}{ }^{-}$increased slightly, 
from $56.7 \%$ to $57.7 \%$ (Figure 3). For the second scenario, using all available estimates of $\mathrm{NO}_{3}{ }^{-}$uptake, the stand uptake of $\mathrm{NO}_{3}{ }^{-}$increased from 17.6 to $20.5 \mathrm{~kg} \mathrm{~N} \mathrm{ha}^{-1} \mathrm{yr}^{-1}(2.6 \%)$ and uptake of $\mathrm{NH}_{4}{ }^{+}$increased from 13.1 to $14.7 \mathrm{~kg} \mathrm{~N} \mathrm{ha}^{-1} \mathrm{yr}^{-1}$ (1.5\%) from 1959 to 2001. In addition, the percent of total stand uptake of $\mathrm{N}$ as $\mathrm{NO}_{3}{ }^{-}$increased slightly $57.4 \%$ to $58.3 \%$ (Figure 3). Thus, in neither of the two scenarios did the observed change in the importance of $A$. saccharum reduce the absolute amount $\mathrm{NO}_{3}{ }^{-}$uptake, and in only one scenario was the relative amount of $\mathrm{NO}_{3}{ }^{-}$uptake reduced-but this apparent reduction was extremely small.
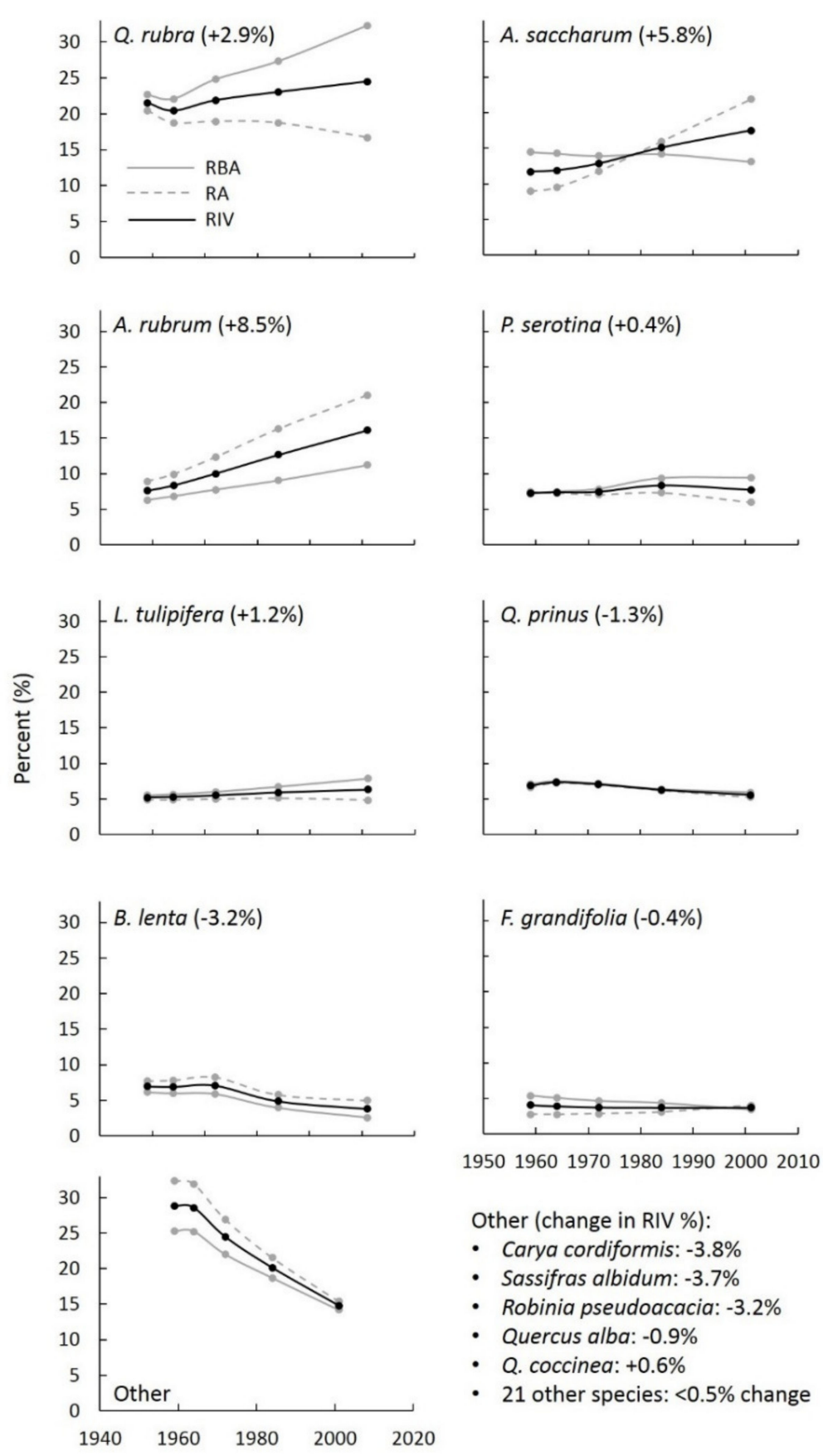

Other (change in RIV \%):

- Carya cordiformis: $-3.8 \%$

- Sassifras albidum: $-3.7 \%$

- Robinia pseudoacacia: $-3.2 \%$

- Quercus alba: $-0.9 \%$

- Q. coccinea: $+0.6 \%$

- 21 other species: $<0.5 \%$ change

Figure 2. Tree species' relative importance, abundance, and basal area (\%) in FEF WS 4 from 1959 to 2001. The percent changes for species listed under "other" are changes in RIV. Data from the USDA Forest Service Northern Research Station [39]. 
Table 2. All available estimates of the percent of total uptake of mineral $\mathrm{N}$ as $\mathrm{NO}_{3}{ }^{-}$and estimated $\mathrm{N}$ uptake rates ( $\mu$ mol $\mathrm{NO}_{3}{ }^{-}-\mathrm{N} \mathrm{g}$ dry $\operatorname{root}^{-1} \mathrm{hr}^{-1}$ ) for A. saccharum. Measurement methods and parameters varied by study.

\begin{tabular}{|c|c|c|c|}
\hline Study & Method & $\begin{array}{c}\text { A. saccharum } \mathrm{N} \text { Uptake } \\
\text { as } \mathrm{NO}_{3}^{-}(\%)\end{array}$ & $\begin{array}{l}\text { Estimated Uptake Rate } \\
\quad\left(\mu \mathrm{mol} \mathrm{N} \mathrm{g} \mathrm{g}^{-1} \mathrm{~h}^{-1}\right)\end{array}$ \\
\hline BassiriRad et al. (1999) & $\begin{array}{c}\text { In situ } \mathrm{N} \text { depletion, excavated } \\
\text { intact roots, } \mathrm{V}_{\max }\end{array}$ & 31 & 9 \\
\hline Eddy et al. (2008) & Excised root ${ }^{15} \mathrm{~N}$ uptake, $\mathrm{V}_{\max }$ & 11.2 & 0.63 \\
\hline Rothstein et al. (1996) & Excised root ${ }^{15} \mathrm{~N}$ uptake, $\mathrm{V}_{\max }$ & 3 & 1.0 \\
\hline Templer and Dawson (2004) & $\begin{array}{l}{ }^{15} \mathrm{~N} \text { addition to seedlings, } \\
\text { greenhouse, roots in native soil }\end{array}$ & 18 & $1.0^{1}$ \\
\hline This study & $\begin{array}{l}\text { In situ }{ }^{15} \mathrm{~N} \text { addition to mature } \\
\text { trees, roots left in native soil }\end{array}$ & 53.6 & $11.6^{2}$ \\
\hline
\end{tabular}

${ }^{1}$ Estimated using the reported values of root biomass, total plant biomass, and $\mathrm{N}$ uptake per total plant biomass. ${ }^{2}$ Estimated assuming that the soil ${ }^{15} \mathrm{~N}$ atom percent after labeling was similar to that of the root after $3 \mathrm{~h}$ of uptake.

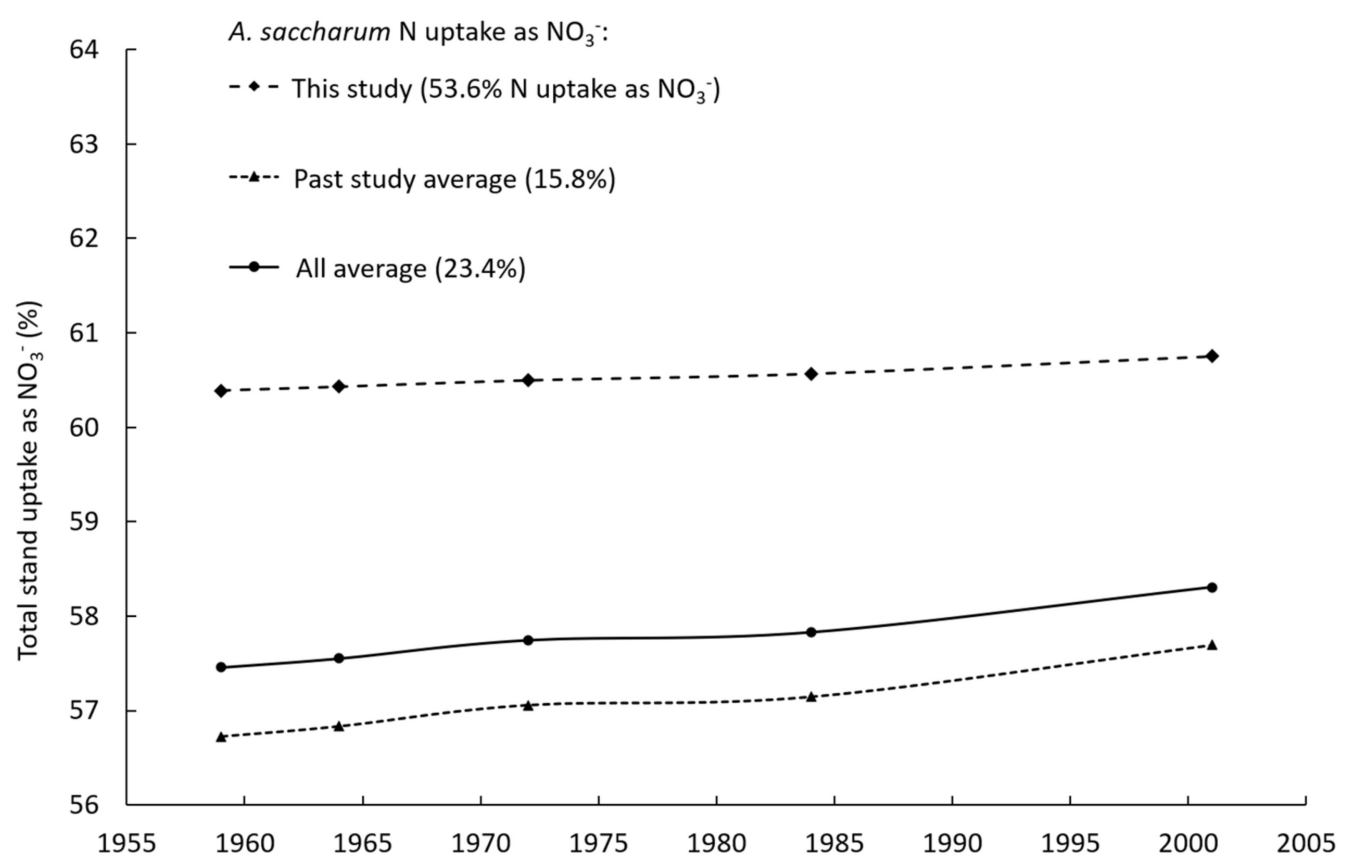

Figure 3. The contribution of $\mathrm{NO}_{3}{ }^{-}$to total stand uptake of $\mathrm{N}$ from 1959 to 2001. Different lines represent different estimates of uptake of $\mathrm{N}_{\text {as }} \mathrm{NO}_{3}{ }^{-}$for $A$. saccharum, based on prior studies, this study, and the average of all available rates.

\section{Discussion}

Unexpectedly, the tree species we considered did not differ in their relative uptake of $\mathrm{NH}_{4}{ }^{+}$and $\mathrm{NO}_{3}{ }^{-}$and utilized significant amounts of both forms in their mineral $\mathrm{N}$ nutrition. This is surprising because prior studies found large differences in the relative uptake of $\mathrm{N}$ as $\mathrm{NH}_{4}{ }^{+}$vs. $\mathrm{NO}_{3}{ }^{-}$for temperate forest species [21,22]. Notably, in past studies, A. saccharum trees took up substantially less $\mathrm{NO}_{3}{ }^{-}$than we found using an in situ ${ }^{15} \mathrm{~N}$-labeling technique (Table 2) [21,32-34], and it seems likely that methodological differences could account for the higher relative $\mathrm{NO}_{3}{ }^{-}$uptake in this study [23]. Most of the prior research on the form of mineral $\mathrm{N}$ uptake utilized seedlings [21], hydroponic techniques [27,46], or $\mathrm{N}$ depletion in a simulated soil solution [20,27] - techniques that do not account for some aspects of in situ soil $\mathrm{N}$ dynamics. Perhaps most importantly, the differential diffusional resistances of $\mathrm{NH}_{4}{ }^{+}$and $\mathrm{NO}_{3}{ }^{-}$in soils [47] are not represented in hydroponic and simulated soil solution techniques. It is possible that tree preferences for $\mathrm{NH}_{4}{ }^{+}$vs. $\mathrm{NO}_{3}{ }^{-}$are dynamic through time, particularly as the rate of $\mathrm{N}$ deposition changes. However, the relative contributions of $\mathrm{NH}_{4}{ }^{+}$and $\mathrm{NO}_{3}{ }^{-}$to total $\mathrm{N}$ deposition have not 
changed substantially (Figure 1), and we therefore believe that large changes in tree $\mathrm{N}$ form preference due to changing relative availability of the two mineral $\mathrm{N}$ forms is unlikely. Thus, assuming that our ${ }^{15} \mathrm{~N}$-labeling experiment is representative of the long-term mineral $\mathrm{N}$ form preference of these tree species, $\mathrm{NO}_{3}{ }^{-}$may contribute more to $\mathrm{N}$ nutrition of trees than previously thought due to the greater rates of transfer of $\mathrm{NO}_{3}{ }^{-}$to roots in the soil.

Since the species examined did not differ in their relative contribution of $\mathrm{NO}_{3}{ }^{-}$to total $\mathrm{N}$ uptake, it seems unlikely that changes in stand composition contributed to the relatively rapid increase in $\mathrm{NO}_{3}{ }^{-}$export or to the long-term persistence of low $\mathrm{N}$ retention via a reduction in the demand by trees for $\mathrm{NO}_{3}{ }^{-}$. Furthermore, since the stand $\mathrm{N}$ demand may have increased over the second half of the last century, it may have contributed to the gradual and slight decrease in soil and stream water $\mathrm{NO}_{3}{ }^{-}$since the early 1980s [48]. Although a forest inventory has not conducted after 2001, there have been no major changes in the stand or significant disturbances in this time. We speculate that the reduction in stream water $\mathrm{NO}_{3}{ }^{-}$concentration circa 2010 resulted from decreasing $\mathrm{N}$ deposition with a significant lag after this decline in deposition started in the early-1990s. Thus, it appears that the large increase observed in $\mathrm{NO}_{3}{ }^{-}$export from WS 4 in approximately 1980 resulted from an enhanced supply of available $\mathrm{NO}_{3}{ }^{-}$via deposition, and the long-term trend in stream water $\mathrm{NO}_{3}{ }^{-}$is controlled primarily by atmospheric $\mathrm{N}$ inputs with a lag in recovery as inputs decline.

Although changes in stand $\mathrm{NO}_{3}{ }^{-}$demand do not seem to account for the increase in $\mathrm{NO}_{3}{ }^{-}$export in stream water, shifts in stand composition could still affect $\mathrm{NO}_{3}{ }^{-}$production in the soil and thus contribute to a lag in the recovery of stream water $\mathrm{NO}_{3}{ }^{-}$export after deposition declines. At several locations in the eastern U.S., A. saccharum trees are associated with high rates of soil net nitrification and low soil C:N ratios [16,31,32,49,50], including WS 4 and other locations in the FEF $[13,15]$, and nitrification rates are positively associated with stream $\mathrm{NO}_{3}{ }^{-}$export [51]. The relationship between $A$. saccharum abundance and nitrification is driven, in part, by relatively labile litter and low $\mathrm{N}$ residence time $[15,52]$. To make an initial assessment of the potential impact of species shifts on soil $\mathrm{NO}_{3}{ }^{-}$production and stream water $\mathrm{NO}_{3}{ }^{-}$export, we used previous plot-level measurements of net nitrification potential and the relative importance and relative basal area of tree species in WS 4 . We estimated that net nitrification potential increases $0.02 \mathrm{~kg} \mathrm{ha}^{-1}$ day $^{-1}$ for every $1 \%$ increase in $A$. saccharum importance value $\left(\mathrm{R}^{2}=0.45\right)$ and decreases $0.017 \mathrm{~kg} \mathrm{ha}^{-1} \mathrm{day}^{-1}$ for every $1 \%$ increase in $A$. rubrum importance value $\left(R^{2}=0.13\right)$ [14]. Similarly, net nitrification potential increases $0.017 \mathrm{~kg} \mathrm{ha}^{-1}$ day $^{-1}$ for every $1 \%$ increase in $A$. saccharum relative basal area $\left(R^{2}=0.20\right)$ and decreases $0.016 \mathrm{~kg} \mathrm{ha}^{-1}$ day $^{-1}$ for every $1 \%$ increase in $A$. rubrum relative basal area $\left(R^{2}=0.12\right)$ When analyzed in the same manner, no other species was associated with significant changes in net nitrification potential. Since A. saccharum and A. rubrum had large changes in relative importance value and basal area from 1959 through 2001, and have opposite associations with net nitrification potential, we assessed their potential impact on soil $\mathrm{NO}_{3}{ }^{-}$supply and $\mathrm{NO}_{3}{ }^{-}$loss to stream water. To arrive at an annual estimate, we assumed that: (1) the estimated daily rate of change in net nitrification potential applied during the months of May through August; (2) only $50 \%$ of the estimated daily rate occurred during March, April, and September through November, when the rate of nitrification is lower [53]; and (3) the species change had no effect on net nitrification potential during the months of December through February, when very little nitrification takes place.

The decline in A. saccharum and increase in A. rubrum relative basal area in WS4 suggest that nitrate production via nitrification was $19.4 \mathrm{~kg} \mathrm{~N} \mathrm{ha}^{-1} \mathrm{yr}^{-1}$ lower in 2001 than in 1959. However, our plot-level data show a stronger relationship between relative importance value and nitrification potential. Furthermore, past studies have detected a strong relationship between soil $\mathrm{NO}_{3}{ }^{-}$concentration and A. saccharum abundance [31,54]. Thus, using the relationship between these species' relative importance values and nitrification potential, our initial approximation suggests that the effects of A. saccharum and A. rubrum on soil $\mathrm{NO}_{3}{ }^{-}$production from 1959 to 2001 mostly offset each other, with the 
negative effect of $A$. rubrum on nitrification causing a net decrease in the rate of $\mathrm{NO}_{3}{ }^{-}$ production of $2.6 \mathrm{~kg} \mathrm{NO}_{3}{ }^{-}-\mathrm{N} \mathrm{ha}^{-1} \mathrm{yr}^{-1}$ within WS 4 . However, the majority of the increase observed in the importance of $A$. rubrum occurred in a silvicultural compartment of the watershed (compartment WS 4c) that produces very little $\mathrm{NO}_{3}{ }^{-}$in the soil, and that has very low $\mathrm{NO}_{3}{ }^{-}$concentrations in soil water collected by tension-free lysimeters [55]. Thus, it is unlikely that this region of the WS 4 contributed to the observed patterns in stream $\mathrm{NO}_{3}{ }^{-}$export. Additionally, this subcompartment contains no A. saccharum trees, so the increased importance of this species only occurred in the portions of the watershed where nitrification and soil solution $\mathrm{NO}_{3}{ }^{-}$levels are currently much higher $[13,55]$. Although it is unclear why $A$. saccharum has increased in importance at this site, we believe that this is a long-term successional change due to the decline of other subcanopy species.

Considering these known spatial patterns in $\mathrm{NO}_{3}{ }^{-}$availability, we refined our initial assessment to $\sim 86 \%$ of WS 4 by excluding compartment WS $4 \mathrm{c}$ where $\mathrm{NO}_{3}{ }^{-}$availability is very low. Taking this approach, we estimate that the net effect of changes in the importance of $A$. saccharum and $A$. rubrum was to increase soil $\mathrm{NO}_{3}{ }^{-}$production by $3.9 \mathrm{~kg} \mathrm{NO}_{3}{ }^{-}-\mathrm{N} \mathrm{ha}^{-1} \mathrm{yr}^{-1}$ from 1959 through 2001. The long-term change in species composition resulted in a $2.7 \mathrm{~kg} \mathrm{~N} \mathrm{ha}^{-1} \mathrm{yr}^{-1}$ increase in $\mathrm{NO}_{3}{ }^{-}$demand, which mostly offsets the estimated increase in soil $\mathrm{NO}_{3}{ }^{-}$production. Thus, we estimate that a net increase of $1.2 \mathrm{~kg} \mathrm{NO}_{3}{ }^{-}-\mathrm{N} \mathrm{ha}^{-1} \mathrm{yr}^{-1}$ was available for leaching into stream water. Consequently, it seems that patterns of $\mathrm{NO}_{3}{ }^{-}$export were primarily driven by long-term changes in $\mathrm{N}$ deposition, but changes in tree species composition may have contributed an increase in soil $\mathrm{NO}_{3}{ }^{-}$production and thus to a lag in the recovery of stream water $\mathrm{NO}_{3}{ }^{-}$export, which remained $3.5 \mathrm{~kg} \mathrm{~N} \mathrm{ha}^{-1} \mathrm{yr}^{-1}$ higher from 1992 to $2001\left(\sim 5.0 \mathrm{~kg} \mathrm{NO}_{3}{ }^{-}-\mathrm{N} \mathrm{ha}^{-1} \mathrm{yr}^{-1}\right)$ (Figure 1) than the export that occurred from 1970 to $1979\left(\sim 1.5 \mathrm{~kg} \mathrm{NO}_{3}^{-}-\mathrm{N} \mathrm{ha}^{-1} \mathrm{yr}^{-1}\right)$.

This first-order estimate illustrates that understanding the effect of $\mathrm{N}$ deposition on the temporal dynamics of stream water $\mathrm{NO}_{3}{ }^{-}$loss requires a relatively complete understanding of how changes in forest species composition can influence the balance between nutrient supply and demand. Moreover, the spatial patterning of $\mathrm{N}$ supply and demand within a watershed and connectivity to stream discharge and $\mathrm{N}$ export may also be important. We suggest that the recent reductions in atmospheric inputs of $\mathrm{N}$ in the eastern US may result in a delayed return of stream water $\mathrm{NO}_{3}{ }^{-}$losses to "baseline" levels in situations where a long-lasting shift in the composition of tree species changes the inherent rates of $\mathrm{soil} \mathrm{NO}_{3}{ }^{-}$ production and biotic $\mathrm{NO}_{3}{ }^{-}$demand.

Author Contributions: M.B.B. and W.T.P. designed this study; M.B.B., M.J.C. and M.B.A. performed the research and analyzed data; M.B.B. and W.T.P. wrote this paper. All authors have read and agreed to the published version of the manuscript.

Funding: This research was funded by the Long-Term Research in Environmental Biology (LTREB) program at the National Science Foundation (Grant Nos. DEB-0417678, DEB-1019522, and DEB-1455785).

Data Availability Statement: Relevant data can be accessed in a GitHub repository at https:/ / github. $\mathrm{com} /$ markbburnham/Forests-Species-Nitrate-Appalachia (accessed on 3 June 2021).

Acknowledgments: We thank Thomas Schuler and the Fernow Experimental Forest personnel for providing and maintaining the long-term data sets for WS 4, and for access to the field site. We also thank Christopher Walter, Rachel Arrick, Jessica Graham, and Hoff Lindberg for their help with the stable isotope-labeling field experiment.

Conflicts of Interest: The authors declare no conflict of interest. 


\section{Appendix A}

Table A1. Species-specific constants $(\alpha)$ used in woody $\mathrm{N}$ storage estimation.

\begin{tabular}{ll}
\hline Species & A \\
\hline Acer rubrum & 0.149 \\
Acer saccharum & -0.097 \\
Fagus grandifolia & 0.301 \\
Liriodendron tulipifera & 0.338 \\
Magnolia acuminata & 0.276 \\
Nyssa sylvatica & -0.220 \\
Oxydendrum arboreum & 0.187 \\
Prunus serotina & 0.222 \\
Quercus alba & -0.041 \\
Quercus coccinea & 0.304 \\
Quercus prinus & 0.440 \\
Quercus rubra & 0.327 \\
Tilia americana & 0.000 \\
Other species & 0.168 \\
\hline
\end{tabular}

\section{References}

1. Driscoll, C.T.; Lawrence, G.B.; Bulger, A.J.; Butler, T.J.; Cronan, C.S.; Eagar, C.; Lambert, K.F.; Likens, G.E.; Stoddard, J.L.; Weathers, K.C. Acidic deposition in the northeastern United States: Sources and inputs, ecosystems effects, and management strategies. Bioscience 2001, 51, 180-198. [CrossRef]

2. Galloway, J.; Dentener, F.; Capone, D.; Boyer, E.; Howarth, R.; Seitzinger, S.; Asner, G.; Cleveland, C.; Green, P.; Holland, E.; et al. Nitrogen cycles: Past, present, and future. Biogeochemistry 2004, 70, 153-226. [CrossRef]

3. Aber, J.; McDowell, W.; Nadelhoffer, K.; Magill, A.; Bernston, G.; Kamakea, M.; McNulty, S.; Currie, W.; Rustad, L.; Fernandez, I. Nitrogen saturation in temperate forest ecosystems. Bioscience 1998, 48, 921-934. [CrossRef]

4. $\quad$ Edwards, P.J.; Williard, K.W.J.; Wood, F.; Sharpe, W.E. Soil water and stream water chemical responses. In The Fernow Watershed Acidification Study; Adams, M., DeWalle, D., Hom, J., Eds.; Springer: Dordrecht, The Netherlands, 2006; pp. 71-136.

5. Adams, M.B.; Angradi, T.R.; Kochenderfer, J.N. Stream water and soil solution responses to 5 years of nitrogen and sulfur additions at the Fernow Experimental Forest, West Virginia. For. Ecol. Manag. 1997, 95, 79-91. [CrossRef]

6. Boggs, J.L.; Mcnulty, S.G.; Gavazzi, M.J.; Myers, J.M. Tree growth, foliar chemistry, and nitrogen cycling across a nitrogen deposition gradient in southern Appalachian deciduous forests. Can. J. For. Res. 2005, 35, 1901-1913. [CrossRef]

7. Likens, G.E.; Buso, D.C. Dilution and the elusive baseline. Environ. Sci. Technol. 2012, 46, 4382-4387. [CrossRef] [PubMed]

8. Argerich, A.; Johnson, S.L.; Sebestyen, S.D.; Rhoades, C.C.; Greathouse, E.; Knoepp, J.D.; Adams, M.B.; Likens, G.E.; Campbell, J.L.; McDowell, W.H.; et al. Trends in stream nitrogen concentrations for forested reference catchments across the USA. Environ. Res. Lett. 2013, 8, 1-8. [CrossRef]

9. Skjelkvåle, B.L.; Stoddard, J.L.; Jeffries, D.S.; Tørseth, K.; Høgåsen, T.; Bowman, J.; Mannio, J.; Monteith, D.T.; Mosello, R.; Rogora, M.; et al. Regional scale evidence for improvements in surface water chemistry 1990-2001. Environ. Pollut. 2005, 137, 165-176. [CrossRef]

10. Fenn, M.E.; Poth, M.A.; Aber, J.D.; Baron, J.S.; Bormann, B.T.; Johnson, D.W.; Lemly, A.D.; Mcnulty, S.G.; Ryan, D.F.; Stottlemyer, R. Nitrogen excess in North American ecosystems: Predisposing factors, ecosystem responses, and management strategies. Ecol. Appl. 1998, 8, 706-733. [CrossRef]

11. Nadelhoffer, K.; Downs, M.; Fry, B.; Magill, A.; Aber, J. Controls on N retention and exports in a forested watershed. Environ. Monit. Assess. 1999, 55, 187-210. [CrossRef]

12. Goodale, C.L.; Fredriksen, G.; Weiss, M.S.; McCalley, C.K.; Sparks, J.P.; Thomas, S.A. Soil processes drive seasonal variation in retention of $15 \mathrm{~N}$ tracers in a deciduous forest catchment. Ecology 2015, 96, 2653-2668. [CrossRef] [PubMed]

13. Christ, M.; Peterjohn, W.; Cumming, J.; Adams, M. Nitrification potentials and landscape, soil and vegetation characteristics in two Central Appalachian watersheds differing in $\mathrm{NO}_{3}{ }^{-}$export. For. Ecol. Manag. 2002, 159, 145-158. [CrossRef]

14. Lovett, G.M.; Weathers, K.C.; Arthur, M.A.; Schultz, J.C. Nitrogen cycling in a northern hardwood forest: Do species matter? Biogeochemistry 2004, 67, 289-308. [CrossRef]

15. Peterjohn, W.T.; Harlacher, M.A.; Christ, M.J.; Adams, M.B. Testing associations between tree species and nitrate availability: Do consistent patterns exist across spatial scales? For. Ecol. Manag. 2015, 358, 335-343. [CrossRef]

16. Lovett, G.M.; Weathers, K.C.; Arthur, M.A. Control of nitrogen loss from forested watersheds by soil carbon: Nitrogen ratio and tree species composition. Ecosystems 2002, 5, 712-718. [CrossRef]

17. Campbell, J.L.; Hornbeck, J.W.; Mitchell, M.J.; Adams, M.B.; Castro, M.S.; Driscoll, C.T.; Kahl, J.S.; Kochenderfer, J.N.; Likens, G.E.; Lynch, J.A.; et al. Input-output budgets of inorganic nitrogen for 24 forest watersheds in the northeastern United States: A review. Water Air Soil Pollut. 2004, 151, 373-396. [CrossRef] 
18. Peterjohn, W.T.; Adams, M.B.; Gilliam, F.S. Symptoms of nitrogen saturation in two central Appalachian hardwood forest ecosystems. Biogeochemistry 1996, 35, 507-522. [CrossRef]

19. Schuler, T.; Gillespie, A. Temporal patterns of woody species diversity in a central Appalachian forest from 1856 to 1997. J. Torrey Bot. Soc. 2000, 127, 149-161. [CrossRef]

20. McFarlane, K.J.; Yanai, R.D. Measuring nitrogen and phosphorus uptake by intact roots of mature Acer saccharum Marsh., Pinus resinosa Ait., and Picea abies (L.) Karst. Plant Soil 2006, 279, 163-172. [CrossRef]

21. Templer, P.H.; Dawson, T.E. Nitrogen uptake by four tree species of the Catskill Mountains, New York: Implications for forest N dynamics. Plant Soil 2004, 262, 251-261. [CrossRef]

22. Schulz, H.; Härtling, S.; Stange, C.F. Species-specific differences in nitrogen uptake and utilization by six European tree species. J. Plant Nutr. Soil Sci. 2011, 174, 28-37. [CrossRef]

23. Jacob, A.; Leuschner, C. Complementarity in the use of nitrogen forms in a temperate broad-leaved mixed forest. Plant Ecol. Divers. 2014, 1-16. [CrossRef]

24. Rennenberg, H.; Wildhagen, H.; Ehlting, B. Nitrogen nutrition of poplar trees. Plant Biol. 2010, 12, 275-291. [CrossRef] [PubMed]

25. DesRochers, A.; van den Driessche, R.; Thomas, B.R. The interaction between nitrogen source, soil pH, and drought in the growth and physiology of three poplar clones. Can. J. Bot. 2007, 85, 1046-1057. [CrossRef]

26. Buchmann, N.; Schultz, E.; Gebauer, G. 15N-ammonium and 15N-nitrate uptake of a 15-Year-Old Picea abies plantation. Oecologia 1995, 102, 361-370. [CrossRef]

27. Gessler, A.; Schneider, S.; Von Sengbusch, D.; Weber, P.; Haneman, U.; Huber, C.; Rothe, A.; Kreutzer, K.; Rennenberg, H. Field and laboratory experiments on net uptake of nitrate and ammonium by the roots of spruce (Picea abies) and beech (Fagus sylvatica) trees. New Phytol. 1998, 138, 275-285. [CrossRef]

28. Gessler, A.; Jung, K.; Gasche, R.; Papen, H.; Heidenfelder, A.; Börner, E.; Metzler, B.; Augustin, S.; Hildebrand, E.; Rennenberg, H. Climate and forest management influence nitrogen balance of European beech forests: Microbial $\mathrm{N}$ transformations and inorganic N net uptake capacity of mycorrhizal roots. Eur. J. For. Res. 2005, 124, 95-111. [CrossRef]

29. Malagoli, M.; Canal, A.D.; Quaggiotti, S.; Pegoraro, P.; Bottacin, A. Differences in nitrate and ammonium uptake between Scots pine and European larch. Plant Soil 2000, 221, 1-3. [CrossRef]

30. Gallet-Budynek, A.; Brzostek, E.; Rodgers, V.L.; Talbot, J.M.; Hyzy, S.; Finzi, A.C. Intact amino acid uptake by northern hardwood and conifer trees. Oecologia 2009, 160, 129-138. [CrossRef] [PubMed]

31. Lovett, G.; Mitchell, M. Sugar maple and nitrogen cycling in the forests of Eastern North America. Front. Ecol. Environ. 2004, 2, 81-88. [CrossRef]

32. Rothstein, D.E.; Zak, D.R.; Pregitzer, K.S.; Url, S.; Zak, R. Nitrate deposition in northern hardwood forests and the nitrogen metabolism of Acer saccharum marsh. Oecologia 1996, 108, 338-344. [CrossRef] [PubMed]

33. BassiriRad, H.; Prior, S.; Norby, R.; Rogers, H. A field method of determining NH4+ and NO3- uptake kinetics in intact roots: Effects of CO2 enrichment on trees and crop species. Plant Soil 1999, 217, 195-204. [CrossRef]

34. Eddy, W.C.; Zak, D.R.; Holmes, W.E.; Pregitzer, K.S. Chronic Atmospheric $\mathrm{NO}_{3}{ }^{-}$Deposition Does Not Induce $\mathrm{NO}_{3}{ }^{-}$Use by Acer saccharum Marsh. Ecosystems 2008, 11, 469-477. [CrossRef]

35. Crabtree, R.; Bazzaz, F. Seedling response of four birch species to simulated nitrogen deposition: Ammonium vs. nitrate. Ecol. Appl. 1993, 3, 315-321. [CrossRef]

36. Kochenderfer, J.N. Fernow and the Appalachian Hardwood Region. In The Fernow Watershed Acidification Study; Adams, M., DeWalle, D., Hom, J., Eds.; Springer: Dordrecht, The Netherlands, 2006; pp. 17-39.

37. Reinhart, K.; Eschner, A.; Trimble, G. US Forest Service Research Paper NE-I. Effect on Streamflow of Four Forest Practices in the Mountains of West; Upper Darby: Virginia, PA, USA, 1963.

38. Edwards, P.J.; Wood, F. USDA Forest Service Northern Forest Experimental Station General Technical Report NE-177. Field and Laboratory Quality Assurance/Quality Control Protocols and Accomplishments for the Fernow Experimental Forest Watershed Acidification Study; Forest Service: Radnor, PA, USA, 1993.

39. Schuler, T.M.; Wood, F. Fernow Experimental Forest watershed 4 overstory tree data, 1959-2001; U.S. Department of Agriculture Forest Service, Northern Research Station: Parsons, WV, USA, 2015.

40. Bremner, J.M.; Mulvaney, C.S. N-Total. In Methods of Soil Analysis. Part 2; Page, A.L., Ed.; American Society of Agronomy and Soil Science Society of America: Madison, WI, USA, 1982; pp. 595-624.

41. Brenneman, B.; Frederick, D.; Gardner, W.; Schoenhofen, L.; Marsh, P. Biomass of species and stands of West Virginia hardwoods. In Proceedings of the 2nd Central Hardwood Forest Conference, West Lafayette, IN, USA, 14-16 November 1978; pp. $159-178$.

42. McKane, R.B.; Johnson, L.C.; Shaver, G.R.; Nadelhoffer, K.J.; Rastetter, E.B.; Fry, B.; Giblin, A.E.; Kielland, K.; Kwiatkowski, B.L.; Laundre, J.A.; et al. Resource-based niches provide a basis for plant species diversity and dominance in arctic tundra. Nature 2002, 415, 68-71. [CrossRef]

43. Thornton, B.; Osborne, S.M.; Paterson, E.; Cash, P. A proteomic and targeted metabolomic approach to investigate change in Lolium perenne roots when challenged with glycine. J. Exp. Bot. 2007, 58, 1581-1590. [CrossRef]

44. Burnham, M.B.; Cumming, J.R.; Adams, M.B.; Peterjohn, W.T. Soluble soil aluminum alters the relative uptake of mineral nitrogen forms by six mature temperate broadleaf tree species: Possible implications for watershed nitrate retention. Oecologia 2017. [CrossRef]

45. Fry, B. Stable Isotope Ecology, 1st ed.; Springer: New York, NY, USA, 2006; ISBN 0-387-33745-8. 
46. Kronzucker, H.J.; Siddiqi, M.Y.; Glass, A.D.M. Conifer root discrimination against soil nitrate and the ecology of forest succession. Nature 1997, 385, 59-61. [CrossRef]

47. Chapman, N.; Miller, A.J.; Lindsey, K.; Whalley, W.R. Roots, water, and nutrient acquisition: Let's get physical. Trends Plant Sci. 2012, 17, 701-710. [CrossRef]

48. Gilliam, F.S.; Adams, M.B. Effects of nitrogen on temporal and spatial patterns of nitrate in streams and soil solution of a central hardwood forest. ISRN Ecol. 2011, 2011, 1-9. [CrossRef]

49. Pastor, J.; Aber, J.D.; Mcclaugherty, C.A.; Melillo, J.M. Aboveground production and N and P cycling along a nitrogen mineralization gradient on Blackhawk Island, Wisconsin. Ecology 1984, 65, 256-268. [CrossRef]

50. Zak, D.R.; Pregitzer, K.S. Spatial and temporal variability of nitrogen cycling in northern Lower Michigan. For. Sci. 1990, 36, 367-380.

51. Ross, D.S.; Shanley, J.B.; Campbell, J.L.; Lawrence, G.B.; Bailey, S.W.; Likens, G.E.; Wemple, B.C.; Fredriksen, G.; Jamison, A.E. Spatial patterns of soil nitrification and nitrate export from forested headwaters in the northeastern United States. J. Geophys. Res. Biogeosci. 2012, 117, 1-14. [CrossRef]

52. Pregitzer, K.S.; Zak, D.R.; Talhelm, A.F.; Burton, A.J.; Eikenberry, J.R. Nitrogen turnover in the leaf litter and fine roots of sugar maple. Ecology 2010, 91, 3456-3462. [CrossRef] [PubMed]

53. Gilliam, F.S.; Yurish, B.M.; Adams, M.B. Temporal and spatial variation of nitrogen transformations in nitrogen-saturated soils of a central Appalachian hardwood forest. Can. J. For. Res. 2001, 31, 1768-1785. [CrossRef]

54. Mitchell, M.J. Nitrate dynamics of forested watersheds: Spatial and temporal patterns in North America, Europe and Japan. J. For. Res. 2011, 16, 333-340. [CrossRef]

55. Peterjohn, W.T.; Foster, C.J.; Christ, M.J.; Adams, M.B. Patterns of nitrogen availability within a forested watershed exhibiting symptoms of nitrogen saturation. For. Ecol. Manag. 1999, 119, 247-257. [CrossRef] 